ZOOLOGIA 28 (6): 739-746, December, 2011

doi: $10.1590 /$ S1984-46702011000600006

\title{
Downstream passage of fish larvae and eggs through a small-sized reservoir, Mucuri River, Brazil
}

\author{
Paulo S. Pompeu'; Lorena B. Nogueira²; Hugo P. Godinho² \& Carlos B. Martinez \\ ${ }^{1}$ Departamento de Biologia, Universidade Federal de Lavras. Caixa Postal 3037, 37200-000 Lavras, MG, Brazil. \\ E-mail: pompeu@ufla.br \\ 2 Programa de Pós-graduação em Zoologia de Vertebrados, Pontifícia Universidade Católica. Avenida Dom José Gaspar 500, \\ 30535-901 Belo Horizonte, MG, Brazil. \\ ${ }^{3}$ Hydraulic Research Center, Universidade Federal de Minas Gerais. Avenida Antônio Carlos 6627, 31270-901 Belo \\ Horizonte, MG, Brazil.
}

\begin{abstract}
In South America, one important symptom of the failure of fish passages to sustain fish migratory recruitment is the inability of eggs and larvae to reach the nurseries. This is especially so when the breeding areas are located upstream of a reservoir, and the floodplain is downstream of the dam. Therefore, the transport of fish larvae and eggs across reservoir barriers is a key factor in the development of effective conservation strategies. In this paper, we evaluate the potential for migratory fish larvae and egg transportation across a small size reservoir in eastern Brazil. We sampled fish daily between $15^{\text {th }}$ October 2002 and $15^{\text {th }}$ February 2003 (spawning period) in the Mucuri River, immediately upstream of the reservoir and downstream of the Santa Clara Power Plant dam. Our study was the first to indicate the possibility of successful larval passage through the reservoir of a hydroelectric reservoir and dam in South America, and showed that the passage of migratory fish larvae was associated significantly with residence time of water in the reservoir. The relatively short water residence time and elevated turbidity of the Santa Clara's reservoir waters during the rainy season certainly contributed to the successful passage, and can be considered as key factors for a priori evaluations of the feasibility of a downstream larval passage.
\end{abstract}

KEY WORDS. Conservation; downstream passage; drift larvae; migratory fish; reservoir management.

In South America, several freshwater fish species are migratory, moving long distances along the rivers during their life cycle. Although only a small fraction of the South American species are long-distance migrants (Petrere JR 1985, GodinHo $\&$ Godinho 1994), they are the most economically important for professional fishing, due to their abundance (Goulding 1979, Bittencourt \& Cox-Fernandes 1990, Godinho 1993), as well as for amateur fishing, due to their larger size (Northсоте 1978). Migration takes place in a wide range of taxa occurring in South America, although the most conspicuous migrations are principally associated with the Characiformes and Siluriformes orders (CAROLSFELD et al. 2003).

In general, freshwater fish migration in South America can be described as follows. During the wet season, movements involve spawning migrations of adults upstream, and subsequent downstream movements of the spent adults, followed by similar displacements of the larvae (Petrere 1985). The larvae are passively transported to the floodplains (nurseries) along the riverbanks, where they find favorable conditions for shelter and feeding (Agostinho \& Zalewski 1995, Lowe-McConnell 1999).
The migratory fish stocks in Brazil have been depleted by overfishing, land use impacts on the watershed and, especially, by dam construction (AgostinHo et al. 2005). However, the Brazilian hydropower companies are obliged to protect migratory fish species, either by incorporating fish ladders in the dam design to permit migration, or by creating breeding facilities to produce fingerlings of the affected native species for stocking the upstream reservoir (SUGUNAN 1997).

Over time, environmental legislation has made fish stocking and control of the fisheries the main and, in some cases, the only strategy for conservation of these species (AgostinHo et al. 2007a). Although these management practices continue to be used throughout the country, very few studies have evaluated their efficiency and cost-effectiveness in fostering the recuperation of threatened species and populations (VIEIRA \& POMPEU 2001). In fact, the low fishery yields reported from reservoirs located in the South and South-East regions of Brazil, with a significant reduction in the abundance of migratory species (CESP 1996, AgostinHo et al. 1994), clearly indicate that current management strategies are not satisfactory (AgostinHo et al. 2004, 2007a). 
The construction of fish passages was an additional strategy adopted by the Brazilian energy sector in order to ameliorate the negative effects of dam barriers on fish communities, and in particular the migratory species. However, recent studies suggest that some fish passages may be having damaging effects on Neotropical migratory fishes (AgostinHo et al. 2002, 2007b, c, Fernandez et al. 2004, Oldani et al. 2007, Makrakis et al. 2007) and that, in some cases, they could develop into ecological traps (Pelicice \& Agostinho 2008).

One important symptom of when fish passages fail to sustain fish migratory recruitment is the inability of eggs and larvae to reach the nurseries. This is especially so when the breeding areas are located upstream of the reservoir, and the floodplain is downstream of the dam. Studies concerning ichthyoplankton drift though large reservoirs indicate the virtual disappearance of eggs and larvae in their lower parts, attributing the losses to high mortality rates (Agostinho \& Gomes 1997). In these cases, transposed populations do not recruit, or do not contribute to the recruitment, downstream of the dam.

Therefore, the transport of fish larvae and eggs across reservoir barriers is key to the development of effective conservation strategies, and needs to be investigated for reservoirs of different sizes and different water residence periods. In this paper, we evaluate the potential for migratory fish larvae and egg transportation across a small size reservoir in eastern Brazil.

\section{MATERIAL AND METHODS}

The Mucuri River forms part of a network of watersheds which drain the east of Brazil, comprising a total drainage area of $15,100 \mathrm{~km}^{2}$ (CETEC 1983). The hydrological regime of the Mucuri River basin is characterized by two well-defined seasons, dry and wet, with larger water flows occurring between November and April, when most of the region's fish are breeding (POMPEU \& Martinez 2007). The river can be divided into two distinct environmental units, according to particular physiographic characteristics. The upper and middle courses are steeply inclined with numerous rapids and a predominant rocky river bed. In contrast, the lower course is characterized by a deposition system, a gentle decline, a predominantly sandy river bed, and by seasonally flooded Atlantic rain forest (Mata Atlântica) along the river margins (currently dominated by cocoa cultivation), and wetlands and mangroves near the river mouth.

The Santa Clara dam is located on the Mucuri River, in a transitional zone between these two physiographic units, approximately $80 \mathrm{~km}$ from the river's mouth at the Atlantic Ocean (17 $53^{\prime} 51^{\prime \prime} \mathrm{S}, 40^{\circ} 11^{\prime} 50^{\prime \prime} \mathrm{W}$, Fig. 1). The dam construction began in 1999 , and the first turbine became operational in February 2002. The dam wall has a maximum height of $60 \mathrm{~m}$ and is 240 $\mathrm{m}$ in length, supporting a reservoir with an area of $7.5 \mathrm{~km}^{2}$ and a storage volume of $150 \mathrm{hm}^{3}$. There are no tributaries along the seven kilometers length of the reservoir, and the residence time of its water is, on average, 12.8 days. The dam power- house is equipped with three Francis turbine units, operating at 160 rotations per minute. The three independent conventional spillway gates are each $11.5 \mathrm{~m}$ wide and $15.8 \mathrm{~m}$ deep. In November 2003, a fish lift with a trap and truck system became operational in the Santa Clara Hydroelectric Plant. It is located $200 \mathrm{~m}$ downstream of the dam, immediately after the tailrace (Pompeu \& MARTinez 2007).

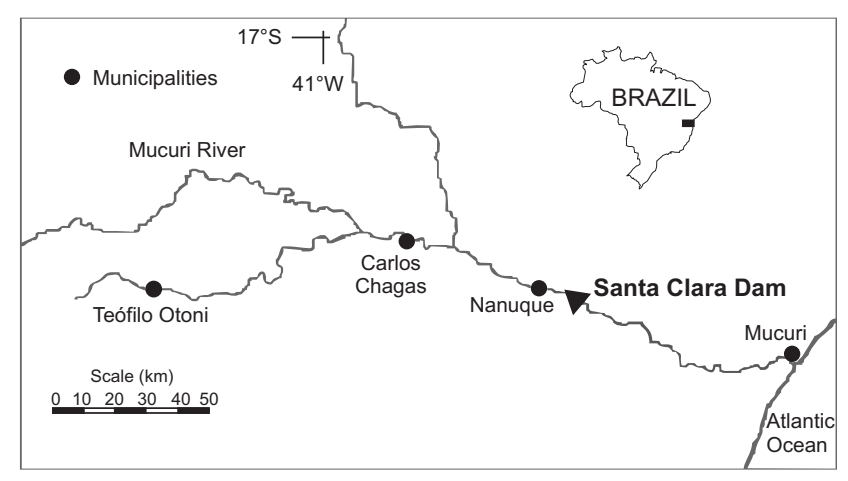

Figure 1. Mucuri basin, indicating the location of Santa Clara Dam.

Since 1996, the fish assemblages of the Mucuri River have been studied, with the result that the migration patterns and population attributes of key species have been determined (Pompeu \& Martinez 2006). At least five freshwater migratory species can be found in the river - Brycon ferox Steindachner, 1877, Leporinus conirostris Steindachner, 1875, L. steindachnerii Eigenmann, 1907, L. copelandii Steindachner, 1875, and Prochilodus vimboides Kner, 1859 - all of them belonging to the order Characiformes. For these species, the location of reproductive areas was found to be upstream of the reservoir, with the nursery areas located downstream. Freshwater species' migrations occurred mainly during the flooding period, from October to March.

We took fish samples daily between $15^{\text {th }}$ October 2002 and $15^{\text {th }}$ February 2003 (spawning period) in the Mucuri River, 0.5 $\mathrm{km}$ upstream of the reservoir's backwater and $300 \mathrm{~m}$ downstream of the Santa Clara dam, immediately after the tailrace. We used conical-cylindrical plankton nets $(0.5 \mathrm{~mm}$ mesh), with a flow meter coupled to the mouth to measure the water velocity through the mouth of the net and the volume of filtered water, placed two meters away from the river bank to collect eggs and larvae. All the samples were taken at 7:00 am upstream and at 7:40 am downstream, using a 20 minute sampling period at each site. Samples were fixed in 5\% formaldehyde, and the abundance of eggs and larvae was standardized using a fixed volume of 1 $\mathrm{m}^{3}$ of filtered water. Larvae were identified to the lowest possible taxonomic level according to NAKATANI et al. (2001), and measured (total length) with a caliper (precision $0.01 \mathrm{~mm}$ ). Larvae of Anostomidae and Prochilodontidae, as well Pimelodidae 
and Loricariidae, were analyzed as single groups. We used a Student's t-test to evaluate differences of body length of migratory Characiformes larvae between the two sampled areas.

Water residence time in the reservoir was calculated daily, taking into account the affluent flow (Santa Clara station) and the average reservoir volume of $150.6 \mathrm{hm}^{3}$. The fortnightly number of eggs and larvae upstream of the reservoir compared to the number of Characiformes larvae downstream of the dam was calculated, and its relationship with the mean water residence time in the reservoir for the period was tested using simple linear regression. Eggs were considered in this analysis only for the upstream samples, since the objective was to evaluate the passage through the reservoir: due to the water residence time, eggs found upstream would reach the dam as larvae.

\section{RESULTS}

During the study period, 1,910 eggs (1820 upstream and 90 downstream), and 259 fish larvae (170 upstream and 89 downstream) were sampled (across all species). The water velocity at the mouth of the net was always superior to $0.1 \mathrm{~m} / \mathrm{s}$, and higher downstream of the dam $($ mean $=0.60 \mathrm{~m} / \mathrm{s} ;$ minimum $=0.22 \mathrm{~m} / \mathrm{s}$ ) when compared to upstream of the reservoir (mean $=0.39$; minimum $=0.14 \mathrm{~m} / \mathrm{s}$ ). During the study period, water residence time in the reservoir ranged from 4.9 to 78.6 days.
The patterns of larvae abundance revealed a strong association with the highest flow rates, and the same high density periods were observed upstream of the reservoir and downstream of the dam (Fig. 2). However, during the flow peaks, the density of eggs upstream of the reservoir was always at least 10 times greater than the density sampled downstream of the dam.

The composition of larvae sampled revealed that Cichlidae, Pimelodidae/Loricariidae and the migratory Anostomidae/Prochilodontidae larvae were the most abundant in both upstream and downstream samples. However, the density of Tetragonopterinae was relevant only downstream of the dam (Tab. I).

When evaluating the temporal distribution for only the migratory Characiformes, their abundance pattern also revealed a strong association with the highest flows upstream of the reservoir and downstream of the dam, but with the highest density peaks being reported only in the first region (Fig. 3). The ratio of upstream eggs and migratory Characiformes larvae upstream of the reservoir, with the number of Characiformes larvae downstream of the dam, was significantly associated with the water residence time in the reservoir (Fig. 4). The density of migratory Characiformes eggs and larvae downstream of the dam was similar to that upstream of the reservoir during the highest flow periods, corresponding to a water residence time of five days. Nineteen days was the longest residence time of water in the
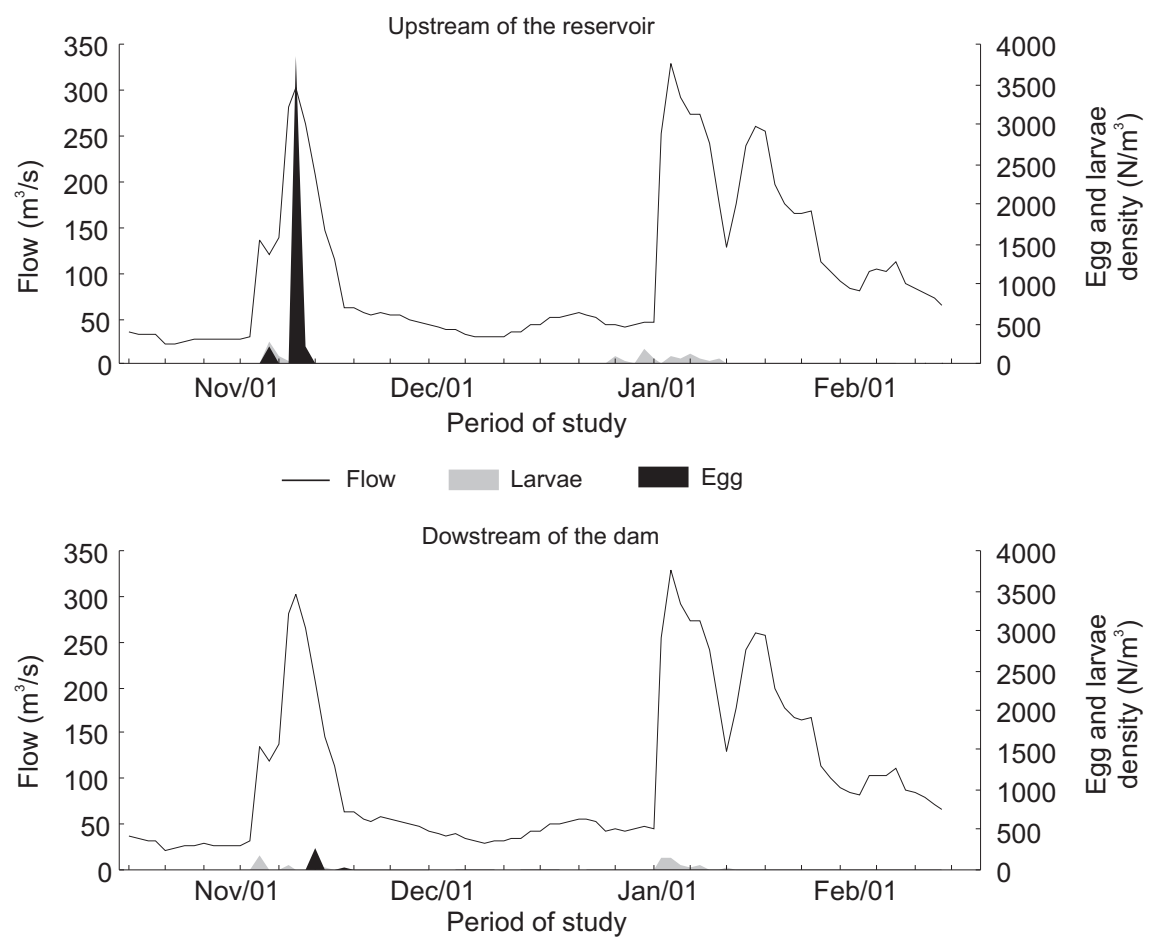

Figure 2. Density of fish eggs and larvae obtained upstream of the reservoir and downstream of the Santa Clara dam, and the flow-rate of the Mucuri River, between October $15^{\text {th }} 2002$ and February $15^{\text {th }} 2003$. 
reservoir in which migratory Characiformes larvae were sampled downstream of the dam. On that occasion, one larvae was found for every 12 eggs and larvae sampled upstream.

The standard length ranged from 2.21 to $6.48 \mathrm{~mm}$ for the identified larvae (Tab. II). However, when comparing the two sampled regions for the migratory Characiformes, the larvae standard length downstream of the dam was significantly lower than that measured from upstream samples (Fig. 5).
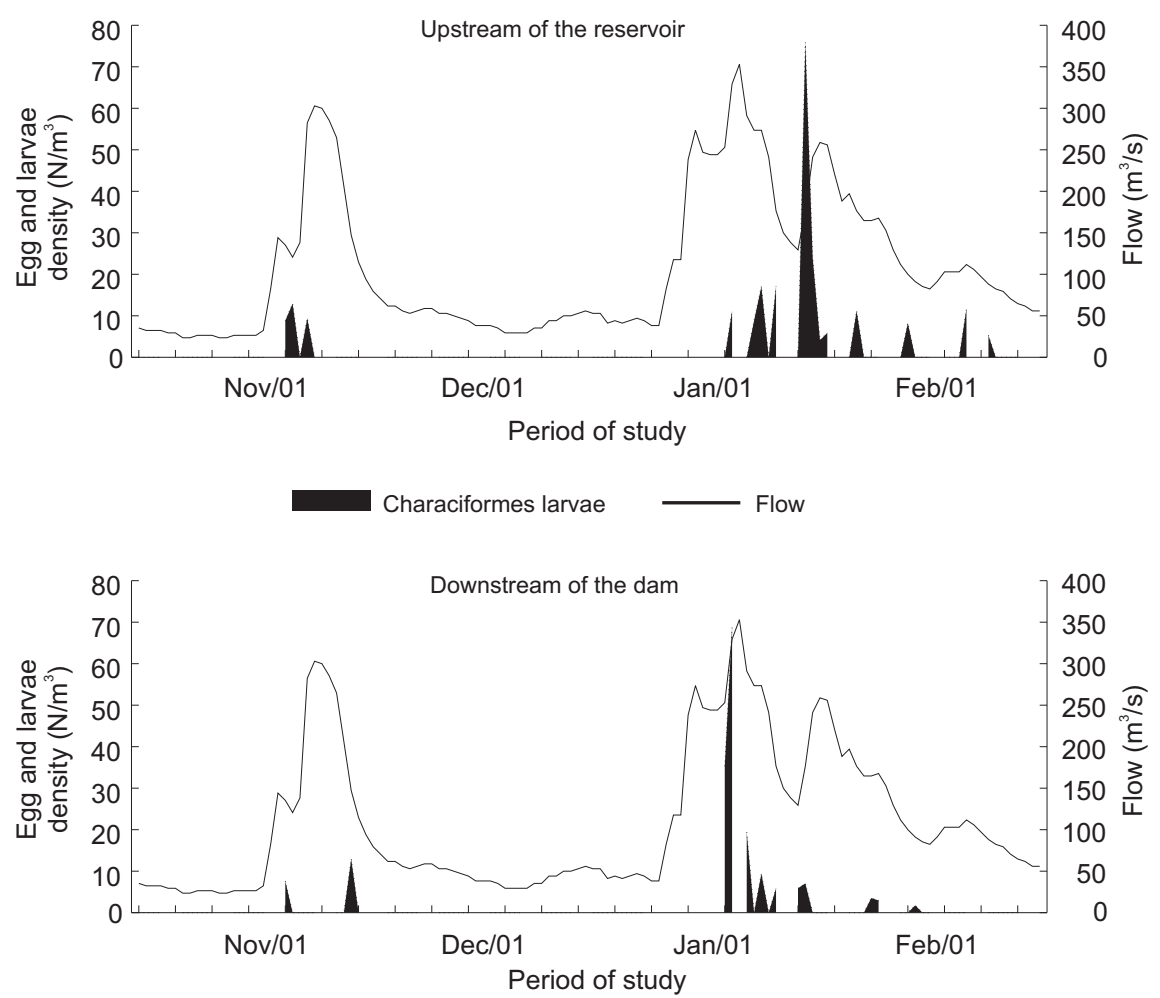

Figure 3. Density of migratory Characiformes larvae obtained upstream of the reservoir and downstream of the Santa Clara dam and Mucuri River flow, between October 15th 2002 and February 152003.
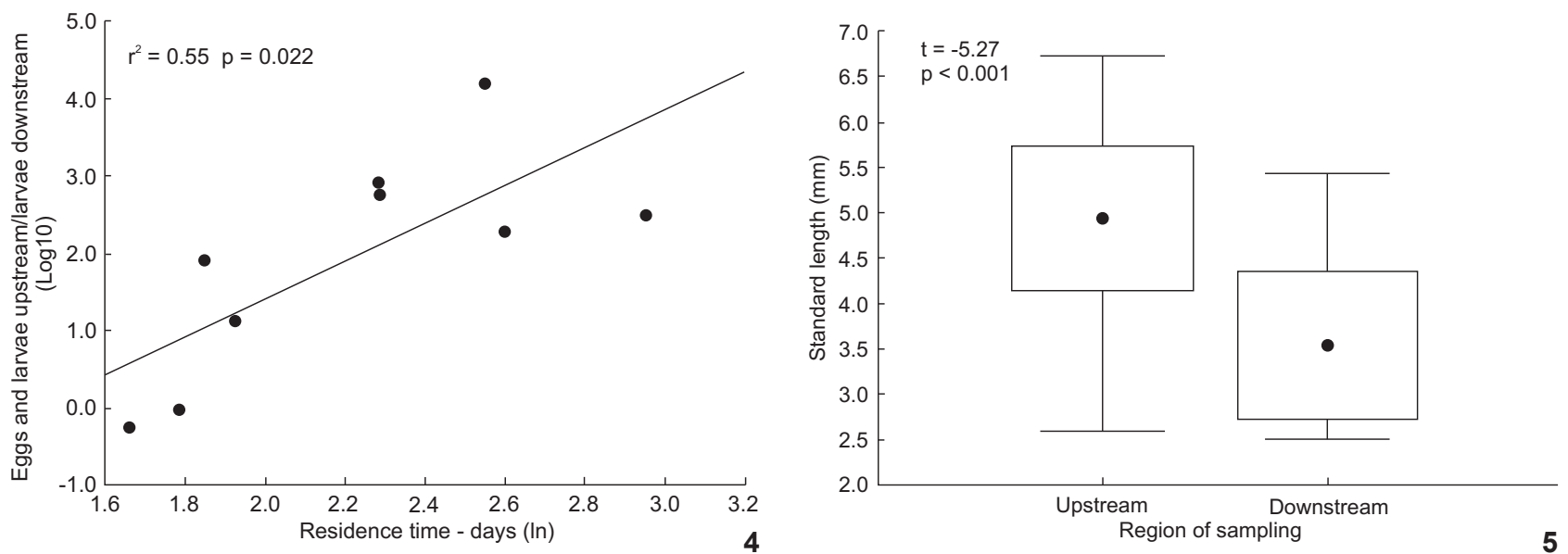

Figures 4-5. (4) Linear regression between the fortnightly number of eggs and larvae upstream of the reservoir, and the number of Characiformes larvae downstream of the dam and the water residence time in the reservoir. (5) Mean (middle point), standard deviation (bar) and amplitude (whisker) of migratory Characiformes larvae standard length, upstream of the reservoir and downstream of the Santa Clara dam.

ZOOLOGIA 28 (6): 739-746, December, 2011 
Table I. Density $\left(\mathrm{n} / \mathrm{m}^{3}\right)$ and relative abundance (\%) of larvae of each taxonomic group and eggs density $\left(\mathrm{n} / \mathrm{m}^{3}\right)$ upstream of the reservoir and downstream of the Santa Clara dam.

\begin{tabular}{|c|c|c|}
\hline \multirow{2}{*}{ Taxonomic groups } & \multicolumn{2}{|c|}{ Sampled regions } \\
\hline & Upstream & Downstream \\
\hline \multicolumn{3}{|l|}{ Characiformes larvae } \\
\hline Erythrinidae & $12.6(10.6 \%)$ & $0(0.0 \%)$ \\
\hline Tetragonopterinae & $3.6(3.0 \%)$ & $8.7(21.7 \%)$ \\
\hline Brycon* & $0(0.0 \%)$ & $2.9(8.7 \%)$ \\
\hline Anostomidae/Prochilodontidae* & $12.6(20.5 \%)$ & $6.4(18.8 \%)$ \\
\hline \multicolumn{3}{|l|}{ Siluriformes larvae } \\
\hline Auchenipteridae & $0(0.0 \%)$ & $0.6(1.5 \%)$ \\
\hline Callichthyidae & $0.9(0.8 \%)$ & $0(0.0 \%)$ \\
\hline Pimelodidae/Loricariidae & $14.3(12.8 \%)$ & $7.0(17.4 \%)$ \\
\hline \multicolumn{3}{|l|}{ Perciformes larvae } \\
\hline Cichlidae & $44.9(37.9 \%)$ & $11.6(29.0 \%)$ \\
\hline Scianidae & $1.8(1.5 \%)$ & $0(0.0 \%)$ \\
\hline Unidentified & $19.9(12.9 \%)$ & $1.6(2.9 \%)$ \\
\hline Eggs & 1632.3 & 52.3 \\
\hline
\end{tabular}

${ }^{*}$ Migratory fish.

Table II. Mean (amplitude) standard length (SL) for each taxonomic group in the two samples.

\begin{tabular}{|c|c|c|c|c|}
\hline \multirow{2}{*}{ Taxonomic groups } & \multicolumn{2}{|r|}{ Downstream } & \multicolumn{2}{|r|}{ Upstream } \\
\hline & $\mathrm{N}$ & $\mathrm{SL}(\mathrm{mm})$ & $N$ & $\mathrm{SL}(\mathrm{mm})$ \\
\hline \multicolumn{5}{|l|}{ Characiformes } \\
\hline Tetragonopterinae & 4 & $2.87(2.57-3.14)$ & 15 & $3.45(3.00-3.84)$ \\
\hline Brycon & & & 6 & $3.99(2.92-6.48)$ \\
\hline $\begin{array}{l}\text { Anostomidae e } \\
\text { Prochilodontidae }\end{array}$ & 27 & $5.08(3.43-6.72)$ & 13 & $3.61(2.88-5.16)$ \\
\hline \multicolumn{5}{|l|}{ Siluriformes } \\
\hline Auchenipteridae & & & 1 & 4.34 \\
\hline Callichthyidae & 1 & 2.35 & & \\
\hline Erythrinidae & 14 & $4.37(2.66-5.52)$ & & \\
\hline Pimelodidae & 16 & $3.11(2.35-4.97)$ & 12 & $3.64(2.50-5.04)$ \\
\hline \multicolumn{5}{|l|}{ Perciformes } \\
\hline Sciaenidae & 2 & $3.06(2.90-3.22)$ & & \\
\hline Cichlidae & 50 & $3.19(2.21-5.76)$ & 20 & $3.17(2.09-3.84)$ \\
\hline Unidentified & 56 & $3.29(1.44-5.52)$ & 22 & $3.46(2.40-3.84)$ \\
\hline
\end{tabular}

\section{DISCUSSION}

Appropriate measurements of larval density depend on the drift pattern of larval fish, including diel and spatial variations, and on larval avoidance of net capture. Although the number of sampled larvae was low, their abundance is not related to sampling design. Downstream migration of riverine lar- vae has been found to be more intense during the night in large rivers, such as the Paraná and Columbia (GADOMSKI \& BARFOOT 1998), but daytime drift is equally intense in the Mississipi and Mekong (Holland 1986). Differences in larval drift fluctuations are largely explained by differences in water transparency and its impact on larval vision (PAvLov 1994). When water transparency is higher, the larvae are able to see and avoid the net during the day, but not by night. In turbid waters, such as the Mucuri River, the low transparency does not interfere with the pattern of net avoidance during the day, and therefore is likely to result in a similar abundance pattern for both day and night samples (Pavlov et al. 1977, Northcote 1982, Araújo Lima et al. 2001). However, in the Velhas, a turbid river in Minas Gerais state, a higher abundance of ichthyoplankton is found during the early morning, the chosen sampling period, indicating nocturnal spawning (Jiménez-SEguRA et al. 2003). In the same study, higher densities of larvae were found near the shoreline (the habitat sampled in our study), when compared with the central river channel. Net avoidance is also often indirectly related to water velocity, that is, the lower the net entrance velocity, the greater the level of avoidance. However, considering larvae swimming performance of between three and seven body lengths per second (Wевв 1975), the water velocity registered passing through the mouth of the net was always greater than the swimming capability of the largest larvae $(4.9 \mathrm{~cm} / \mathrm{s}, 0.7 \mathrm{~cm}$ larvae length).

For fish passages constructed over a dam wall to have a significant effect on the conservation of migratory fishes, they must provide effective connections, allowing the free transit of individuals both upstream and downstream. In particular, they should allow the offspring, resulting from spawning in the upper stretches of the river, to reach the region downstream of the dam (Agostinho et al. 2007b). The elimination of a significant part of the ichthyoplankton population can have important long term effects on the viability of adult populations and the aquatic communities as a whole (CADA \& Hergenrader 1978). The downstream transportation of fish larvae is an aspect of fisheries management that has been frequently ignored in dam mitigation strategies (Quirós 1988). Indeed, the restriction of fish populations to unidirectional migratory movements (upstream) has been invoked as one of the key factors exacerbating the development of fish passages into ecological traps in Neotropical rivers (Pelicice \& Agostinho 2008).

Our study is the first to indicate the possibility of successful larval passage through the reservoir of a hydroelectric reservoir and dam in South America. Migratory fish eggs and larvae drifting down the Tocantins River did not appear in samples taken in the lower half of the reservoir of the Lageado dam (Agostinho et al. 2007b). However, this large reservoir occupies an area almost one hundred times larger than Santa Clara, and the mean residence time of its water is 24 days. The relatively short mean water residence time and elevated turbidity (personal observation) of the Santa Clara's reservoir waters during the rainy season, compared to the Lageado dam, 
certainly contributed to the successful passage, and can be considered as key factors for a priori evaluations of the feasibility of downstream larval passage.

Spawning during the rainy periods, when the river waters are turbid, is an adaptation of migratory fish species to protect eggs and larvae (Agostinho et al. 2002). Therefore, when the offspring encounter, during their downstream migration, a reservoir with elevated transparency levels in the water and a greater number of small-sized predator species favored by the reservoir conditions, their passage can become less viable (Agostinho et al. 2004).

However, the passage through the dam wall itself is another potential source of mortality (CLAY 1995). Causes of mortality are fatal physical contact, the dam head being too high, or reservoir water being oversaturated in gas. Fatal contact can occur against dam structures (dam, spillway, etc.), against downstream passage devices (bypass structures), or against the river bed or banks. Careful design of the spillway or bypass canal can reduce this type of injury, and the plunge pool and tailrace hydraulic conditions will influence the survival of fish downstream (TherRIEN \& BourgeoIs 2000). Nitrogen supersaturation is related to fall head and the deep plunging action of the spill (Clay 1995). Since the probability of contact with the turbine structures and the effects of pressure are related to an individual's size, less than five percent of the ictioplankton is generally affected (CADA et al. 1980, CADA 1990, 1991). The larvae survival after passing through the dam was not quantified in our study. However, at least one type of injury was observed in less than ten percent of the larvae, damage to the caudal fin being the most common.

A marked modification in the ichthyoplancton composition was also observed, especially due to the abundance of Astyanax spp. in the reservoir, reflected in the large proportion of Tetragonopterinae larvae downstream of the dam.

The smaller size of the downstream larvae, when compared to those from the upstream, can probably be explained by the speed of larval development. Available studies on the ontogeny of congeneric migratory species (NAKATANI et al. 2001, GodinHo et al. 2003) indicate that downstream larvae are probably up to four days old, meaning that they would reach the reservoir as eggs. On the other hand, incoming larvae to the reservoir will reach the reservoir at an age of at least five days, when they can actively swim (GodinHo et al. 2003) and avoid the sampling net. However, these larvae could be even younger, since the Mucuri River is usually warmer $\left(30^{\circ} \mathrm{C}\right)$ than those of the congeneric species mentioned by NaKaTani et al. (2001).

The concept of efficiency in management systems must consider both the target species and the biological objectives of the fish passage system (Therrien \& Bourgeois 2000). As important as the fishes' capability to locate the entrance of the mechanism and pass the dam, is the evaluation of its importance and effectiveness in maintaining viable populations of the migratory species, an aspect rarely studied (CADA \& FRANCFORT
1995, Agostinho et al. 2004). Our results indicated that it is possible that migratory species complete their life cycle in the Mucuri River, even though spawning sites are located upstream, and nursery areas downstream, of the Santa Clara Dam. Taking into account the selectivity and efficiency of the fish lift in attracting the shoals (Pompeu \& MarTinez 2006, 2007), it is likely that this mechanism greatly facilitates the conservation of a number of fish species in the Mucuri River. However, only a long term monitoring program of the fish fauna will be able to reveal its efficiency in maintaining viable populations of the region's migratory species.

The water residence time of the reservoir and its turbidity level during the rainy period are key factors that need to be considered in evaluating the feasibility and effectiveness of larval transport to downstream reservoirs in South America - and hence the population viability of migratory fishes. However, additional studies on different sizes of reservoir are necessary in order to establish minimum water residence time and turbity values that permit ichthyoplankton drift, in addition to the potential influence of reservoir shape, water temperature and small predator density in the reservoir, on the downstream larval passage.

\section{ACKNOWLEDGMENTS}

We are grateful to Centrais Elétricas Santa Clara, Limiar Engenharia and The Universidade Federal de Minas Gerais for logistical and financial support, Hernando F. Silva, Ivanildo A. Figueiredo (in memoriam) and Ivo A. Figueiredo for help with the ichthyoplancton sampling, and Toby Gardner for the English review.

\section{LITERATURE CITED}

Agostinho, A.A. \& L.C. Gomes. 1997. Reservatório de Segredo: bases ecológicas para o manejo. Maringá, EDUEM.

Agostinho, A.A. \& M. Zalewski. 1995. The dependence of fish community structure and dinamics on floodplain and riparian ecotone zone in Paraná River, Brazil. Hydrobiologia 303: 141-148.

Agostinho, A.A.; H.F. Julio Jr \& M. Petrere Jr. 1994. Itaipu reservoir (Brazil): impacts of the impoundment on the fish fauna and fisheries, p. 171-184. In: I.G. Cowx (Ed.). Rehabilitation of freshwater fisheries. Oxford, Blackwell.

Agostinho, A.A.; L.C. Gomes; D.R. Fernandez \& H.I Suzuki. 2002. Efficiency of fish ladders for neotropical ichthyofauna. River Research and Applications 18: 299-306. doi: 10.1002/rra.674

Agostinho, A.A.; L.C. Gomes \& J.D. Latini. 2004. Fisheries management in Brazilian reservoirs: lessons from/for South América. Interciência 29 (6): 334-338.

Agostinho, A.A.; S.M. Thomaz \& L.C. Gomes. 2005. Conservation of the Biodiversity of Brazil's Inland Waters. Conservation Biology 19 (3): 646-652. DOI: 10.1111/j.1523-1739.2005.00701.x 
Agostinho, A.A.; L.C. Gomes \& F.M. Pelicice. 2007a. Ecologia e Manejo de Recursos Pesqueiros em Reservatórios do Brasil. Maringá, EDUEM.

Agostinho, A.A.; E.E. Marques; C.S. Agostinho; D.A. Almeida; R.J. Oliveira \& J.R.B. Melo. 2007b. Fish ladder of Lajeado Dam: migrations on one-way routes? Neotropical Ichthyology 5 (2): 121-130. doi: 10.1590/S1679-62252007000200002

Araujo-Lima, C.A.R.M.; V.V. Silva \& P. Petry. 2001. Variação nictimeral na deriva de larvas no Rio Amazonas. Brazilian Journal of Biology 61 (3): 357-362. doi: 10.1590/S151969842001000300003

Bittencourt, M.M. \& C. Cox-Fernandes. 1990. Peixes migradores sustentam pesca comercial. Ciência Hoje 11 (64): 20-24.

CAda, F.G. \& G.L. Hergenrader. 1978. An assessment of sampling mortality of larval fishes. Transactions of the American Fisheries Society 107 (2): 269-274.

CADA, F.G. 1990. A review of studies relating to the effects of propeller-type turbine passage on fish early life stages. North American Journal of Fisheries Management 10: 418-426.

CADA, F.G. 1991. Effects of hydroelectric turbine passage on fish early life stages. Water Power 91: 318-326.

Cada, F.G. \& J.E. Francfort. 1995. Examining the benefits and costs of fish passage and protection measures. Hydro Review 14 (1): 47-55.

CADA, F.G.; J.S SuFrEn; K.D. KuMAR \& J.A. SOlOMON. 1980. Investigations of entrainment mortality among larval and juvenile fishes using a power plant simulator, p. 111-122. In: Proceedings of the fifth national workshop on entrainment and impingement. San Francisco, Electric Power Research Institute.

Carolsfeld, J.B.; C.R. Harvey \& A. Baer. 2003. Migratory fishes of South America: biology, fisheries and conservation status. Ottawa, World Fisheries Trust, The World Bank.

CESP. 1996. Aspectos limnológicos, ictiológicos e pesqueiros de reservatórios da CESP no período de 1986 a 1994. Série Pesquisa e Desenvolvimento 136: 1-81.

CETEC. 1983. Diagnóstico Ambiental do Estado de Minas Gerais. Fundação Centro Tecnológico de Minas Gerais/CETEC. Série de Publicações Técnicas 10: 1-158.

Clay, C.H. 1995. Design of Fishways and Other Fish Facilities. Boca Raton, CRC Press, $2^{\text {nd }}$ ed.

Fernadez, D.R.; A.A. Agostinho \& L.M. Bini. 2004. Selection of an experimental fish ladder located at the dam of the Itaipu Binacional, Paraná river, Brazil. Brazilian Archives of Biology and Technology 47 (4): 579-586. doi: 10.1590/ S1516-89132004000400012

Gadomski, D.M. \& C.A. Barfoot. 1998. Diel and distributional abundance patterns of fish embryos and larvae in the lower Columbia and Deschutes rivers. Environmental Biology of fishes 51: 353-368.

Godinho, A.L. 1993. E os peixes de Minas em 2010? Ciência Hoje 16 (91): 44-49.

GodinHo, H.P. \& A.L. GodinHo. 1994. Ecology and conservation of fish in southeastern Brazilian river basins submitted to hydroelectric impoundments. Acta Limnologica Brasiliensia 5: 187-197.

Godinho, H.P.; J.E. Santos \& Y. Sato. 2003. Ontogênese larval de cinco espécies de peixes do São Francisco, p. 133-148. In: H.P. Godinho \& A.L. GodinHo (Eds). Águas, peixes e pescadores do São Francisco das Gerais. Belo Horizonte, PUC Minas.

Goulding, M. 1979. Ecologia da pesca do rio Madeira. Manaus, CNPq, INPA.

Holland, L.E. 1986. Distribution of early life history stages of fishes in selected pools of the upper Mississipi River. Hydrobiologia 136: 121-130.

Jiménez-Segura, L.F.; A.L. Godinho \& M. Petrere Jr. 2003. As desovas de peixes no alto-médio São Francisco, p. 373-387. In: H.P. Godinho \& A.L. Godinho (Eds). Águas, peixes e pescadores do São Francisco das Minas Gerais. Belo Horizonte, PUC Minas.

Lowe-Mcconnell, R.L. 1999. Estudos ecológicos de comunidades de peixes tropicais. São Paulo, EDUSP.

Makrakis, S.; M.C. Makrakis; R.L. Wagner; J.H.P Dias \& L.C. GoMEs. 2007. Utilization of the fish ladder at the Engenheiro Sergio Motta Dam, Brazil, by long distance migrating potamodromous species. Neotropical Ichthyology 5 (2): 197-204. doi: 10.1590/S1679-62252007000200014

Nakatani, K.; A.A Agostinho; G. Baumgartner; A. Bialetzki; P.V Sanches; M.C Makrakis \& C.S. Pavanelli. 2001. Ovos e larvas de peixes de água doce: desenvolvimento e manual de identificação. Maringá, EDUEM.

Northсоте, T.G. 1978. Migratory strategies in production in freshwater fishes, p. 326-359. In: S.D. GerkING (Ed.). Ecology of freshwater fish production. Oxford, Blakwell Scientific Publications.

Northсоте, T.G. 1982. Mechanism of fish migrations in rivers, p. 317-354. In: J.D. Mccleave; G. Arnold; J. Dodson \& W. NeILL. (Eds). Mechanisms of migration in fishes. New York, Plenum Press.

Oldani, N.O.; C.R.M. Baigún; J.M. Nestler \& R.A. Goodwin. 2007. Is fish passage technology saving fish resources in the lower La Plata River basin? Neotropical Ichthyology 5 (2): 109119. doi: 10.1590/S1679-62252007000200002

PavLov, D.S. 1994. The downstream migration of young fishes in rivers: mechanisms and distribution. Folia Zoologica 43: 193-208.

Pavlov, D.S.; A.M. Pakhorukov; G.N. Kuragina; V.K. Nezdoliy; N.P. Nekrasova; D.A. Brodskiy \& A.L. Ersler. 1977. Some peculiarities of downstream migrations of young fishes in the Volga and the Kuban Rivers. Voprosy ikhthiologii 17 (104): 415428.

Pelicice, F.M. \& A.A. Agostinho. 2008. Fish-Passage Facilities as Ecological Traps in Large Neotropical Rivers. Conservation Biology 22: 180-188. doi: 10.1111/j.1523-1739.2007.00849.x

Petrere Jr, M. 1985. Migraciones de peces de agua dulce en America Latina: algunos comentarios. COPESCAL Documento Ocasional 1: 1-17. 
Pompeu, P.S. \& C.B. Martinez. 2006. Variações temporais na passagem de peixes pelo elevador da Usina Hidrelétrica de Santa Clara, rio Mucuri, leste brasileiro. Revista Brasileira de Zoologia 23 (2): 340-349. doi: 10.1590/S0101-81752006000200005

Pompeu, P.S. \& C.B. Martinez. 2007. Efficiency and selectivity of a trap and truck fish passage system in Brazil. Neotropical Ichthyology 5 (2): 169-176. doi: 10.1590/S1679-62252007 000200011

Quiros, R. 1988. Structures Assisting the Migrations of NonSalmonid Fish: Latin America, FAO Technical Paper 5: 141.

Submitted: 19.V.2011; Accepted: 09.IX.2011.

Editorial responsibility: Walter A. Boeger
SugunAN, V.V. 1997. Fisheries management of small water bodies in seven countries in Africa, Asia and Latin America. FAO Fisheries Circular 933: 1-149.

Therrien, J. \& G. Bourgeois. 2000. Fish Passage at Small Hydro Sites. Ottawa, Report by Genivar Consulting Group for CANMET Energy Technology Centre.

Vieira, F. \& P.S. Pompeu. 2001. Peixamentos: uma alternativa eficiente? Ciência Hoje 30 (175): 28-33.

Wевв, P.W. 1975. Hydrodynamics and energetics of fish propulsion. Bulletin of the Fisheries Research Board of Canada 190: 1-158. 